\title{
The Influence of Leadership and Organizational Culture Against Organizational Citizenship Behavior Environment Mediated by Motivation in AJB Bumiputera 1912
}

\author{
Hari Yansyah Akil ${ }^{1}$, Lenny Chrsitina Nawangsari ${ }^{2}$ \\ \{hariyansyahakil@gmail.com ${ }^{1}$, lenny.christina@mercubuana.ac.id²\} \\ Universitas Mercu Buana, Jakarta, Indonesia ${ }^{12}$
}

\begin{abstract}
A company is formed with the purpose to increase the profit targeted by the company every quarter and year. These targets can be supported and achieved if each employee had an Organizational Citizenship Behavior Environment (OCBE). This study aimed to test and analyze the influence of leadership and organizational culture variables on OCBE in AJB Bumiputera 1912 through motivation as a mediating variable. The research method used a quantitative approach with a causal exploratory design. The sample of this study were 134 respondents using simple random sampling technique. Data collection techniques used a questionnaire instrument with a Likert scale measurement. The data were analyzed using SEM PLS Smart PLS Version 3.2.8 Software. The results of this study indicate that the independent variable has a significant effect on OCBE either directly or through the mediating variable Motivation. The author suggests management to improve leadership, organizational culture and motivation to increase employee voluntary behavior towards the organizational environment.
\end{abstract}

Keywords: Leadership, Organizational Culture, Motivation and Organizational Citizenship Behavior Environment

\section{Introduction}

The success of an organization depends on employees as human resources which is an important element in realizing the vision, mission and goals of a company. OCBE behavior on employees arises from various factors that exist in the organization. OCBE is individual behavior that is free and explicitly gets an award from the formal reward system, and relatively encourages the effectiveness of organizational functions. Achievement of organizational goals is influenced by many aspects that become important in its fulfilment, including the element of leadership. Officers or employees who are not managed properly will not be able to achieve the goals set.

Meanwhile, organizational culture can also play a role to cause OCBE employee behavior in the company. Culture in using company facilities such as electricity, stationery and other facilities contained in the company are things that need to be considered to obtain the efficiency of costs incurred by the company [1]. Culture of using lights as needed, using office stationery facilities for work needs, using other facilities as needed and prioritizing the 
needs of work in the office. Leaders' motivation for employees to implement OCBE culture in the company is also needed [2]. Motivation is an important subject for managers. Existing motivation in a person is a stimulus that will create a behavior to achieve the goal of job satisfaction [3].

Before conducting research, the researcher conducted a pre-survey to determine the OCBE level of employees. Based on the pre-survey data, based on these findings, it can be concluded that OCBE in employees were still low due to several things that less maximum such as Leadership, Organizational Culture, and Motivation. This made the writer chose the title of the study "The Influence of Leadership and Organizational Culture against OCBE Mediated by Motivation in AJB Bumiputera 1912."

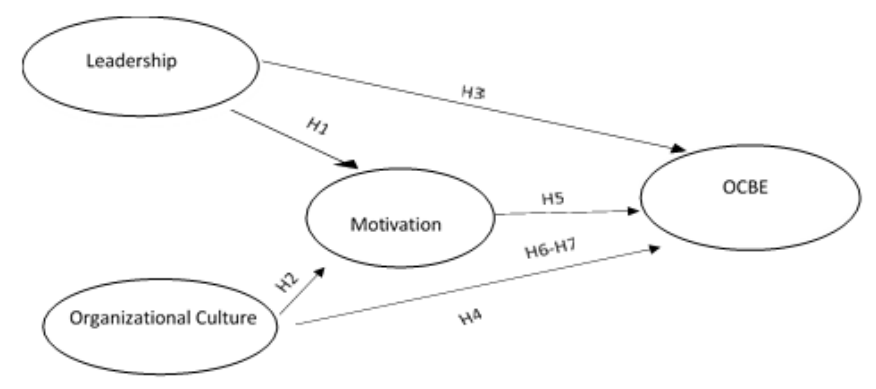

Hypothesis:

Fig 1. Structure of Research Idea (Researcher, 2019)

H1: Leadership X1 has significant effect on motivation Y1 "acceptable".

$\mathrm{H} 2$ : Organizational culture X2 has significant effect on the motivation of Y1 "acceptable".

H3: Leadership X1 was of significant effect on OCBE Y2 "acceptable".

H4: Organizational culture X2 has significant effect on OCBE Y2 "acceptable".

H5: Motivational Y1 has significant effect on the OCBE Y2 "acceptable".

H6: The leadership X1 was of significant effect on the OCBE Y2 through the Y1 motivation variable "acceptable".

H7: Organizational culture X2 has significant effect on the OCBE Y2 through the Y1 motivation variable "acceptable".

\section{Research Method}

The study used a correlative quantitative research method, which is to see the effect of variables Leadership and Organizational Culture of OCBE through Motivation at AJB Bumiputera 1912. The population of this study was all employees of AJB Bumiputera 1912. The population in this study was 200 employees and sample used in this study was 134 employees so that the results of the study were truly accurate. Data was collected according to a quantitative approach that is with the study of literature to underlie and strengthen the results and questionnaires.

The research instrument of Leadership and Organizational Culture variables on OCBE through Motivation in the form of a questionnaire with a Likert scoring model that was filled in by respondents on the questionnaire distributed. Data analysis techniques of this study used Partial Least Square (PLS). Data analysis used step 1) descriptive analysis with 
equation 1 ; 2) test the structural model; 3 ) evaluating the regression value (R2) consisting of 3 classifications: R2 values $0.67,0.33$ and 0.19 as substantial, moderate (moderate) and weak (11). Furthermore, cooperation 2;4) Validate the overall structural model by using the Goodness of Fit Index (GoF) with equation 3; 5) Testing Predictive Relevance (Q2) with equation 4 which has function to validate the model[4].

\section{Results and Discussion}

Outer model is a measurement model to assess the validity and reliability of the model. Through the algorithm iteration process, the measurement model parameters (convergent validity, discriminant validity, composite reliability and Cronbach's alpha) are obtained, including the R2 value as the accuracy parameter of the prediction model, the measurement model is used to test the construct validity and instrument reliability. Validity test is conducted to determine the ability of research instruments to measure what should be measured. While the reliability test is used to measure the consistency of measuring instruments in measuring a concept or it can also be used to measure the consistency of respondents in answering statement items in a questionnaire or research instrument.

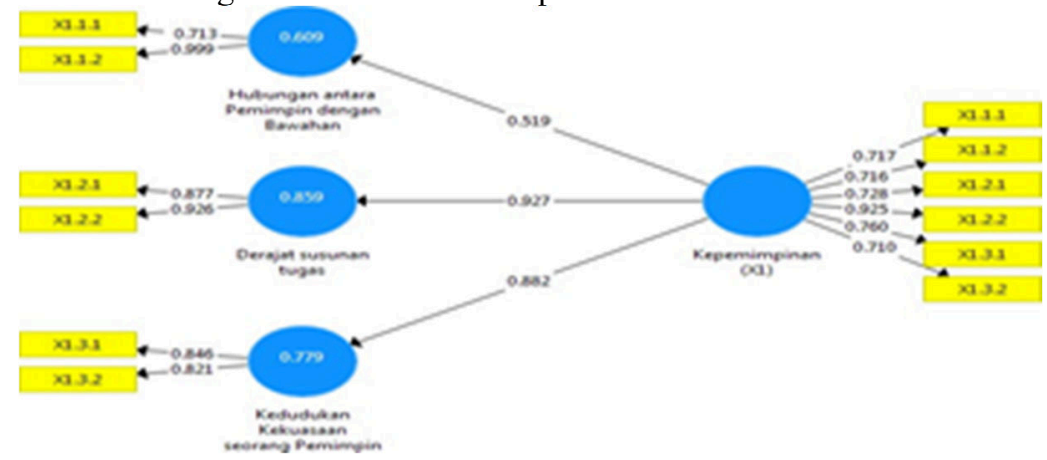

Fig 1. Examination of Outer Model XI Leadership (SmartPLS)

a. The loading factor value of each indicator in the variable and its dimensions are above 0.7. This proves that all indicators of leadership variable X1 used in this study are valid or have met convergent validity [5].

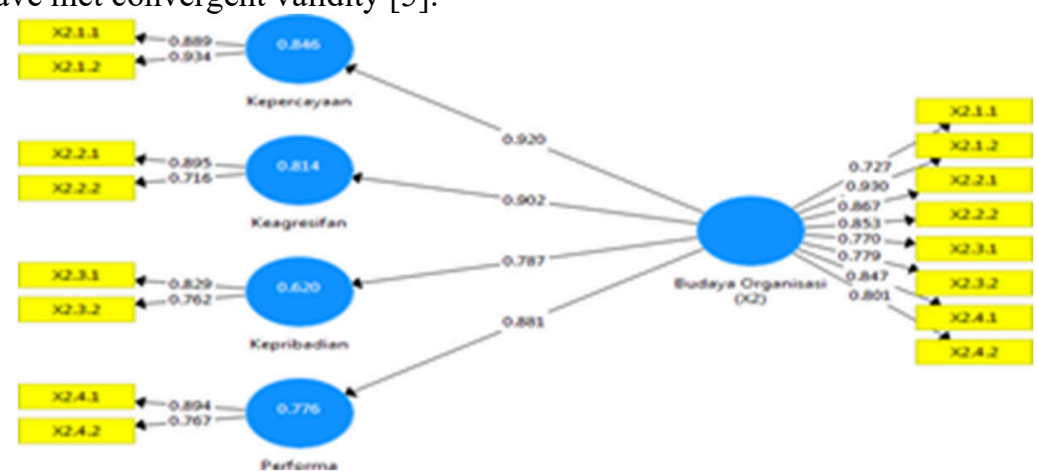

Fig 2. Examination of Outer Model X2 Organizational Culture (SmartPLS) 
b. The loading factor value of each indicator in the variable and its dimensions are above 0.7. This proves that all indicators of the $\mathrm{X} 2$ Organizational Culture variable used in this study are valid or have met convergent validity [6].

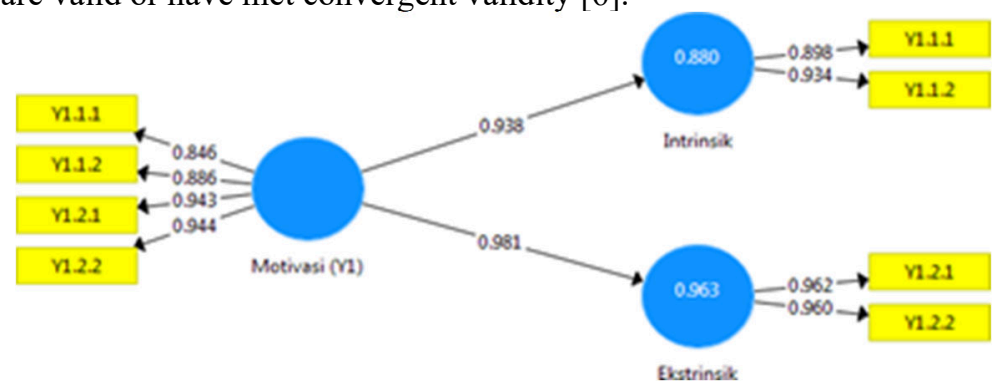

Fig 3. Examination of Outer Model Y1 Motivation (SmartPLS)

c. The loading factor value of each indicator in the variable and its dimensions are above 0.7. This proves that all indicators of the Y1 Motivation variable used in this study are valid or have met the convergent validity [7].

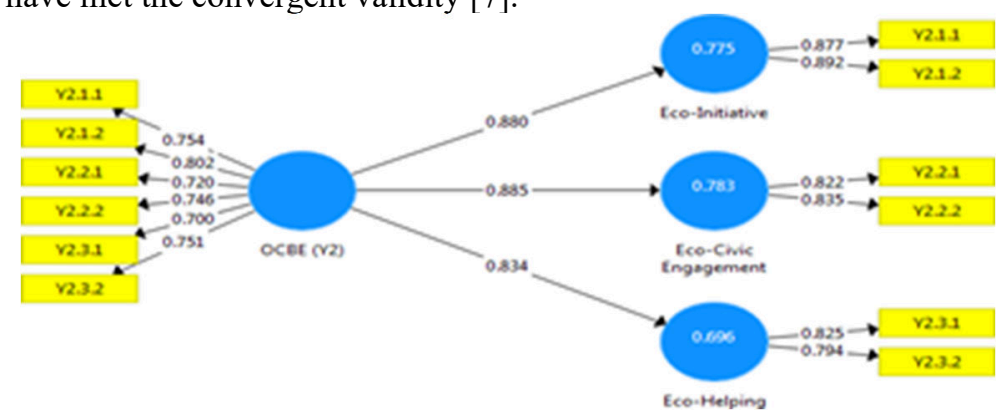

Fig 4. Examination of Outer Model Y2 OCBE

d. The loading factor value of each indicator in the variable and its dimensions are above 0.7 . This proves that all indicators of the OCBE Y2 variable used in this study are valid or have met the convergent validity [5].

Furthermore, the discriminant validity is measured through the cross-loading value and the AVE comparative value and the square root AVE. Another test to evaluate the outer model is to look reliability construct of latent variables measured by two sizes, namely composite reliability and Cronbach alpha from the indicator block that measures the construct. The first stage, the construct is declared reliable if it has a composite reliability value above 0.70 [4] 2. The following is the output from the outer model of AVE and composite reliability.

Table 1. AVE (Average Variance Extracted)

\begin{tabular}{llcc}
\hline \multicolumn{1}{c}{ Variable } & \multicolumn{1}{c}{ Dimension } & $\begin{array}{c}\text { AVE } \\
\text { Value }\end{array}$ & $\begin{array}{c}\text { AVE } \\
\text { Value }\end{array}$ \\
\hline \multirow{2}{*}{ Leadership } & 1.1 Relation between leader and employees & 0.506 & \\
(X1) & 1.2 Degree of job arrangement & 0.813 & 0.520 \\
& 1.3 Authority position of a leader & 0.695 & \\
\hline
\end{tabular}




\begin{tabular}{llll}
\hline & 2.1 Trust & 0.832 & \\
Organizational & 2.2 Aggressiveness & 0.657 & \multirow{2}{*}{0.538} \\
Culture (X2) & 2.3 Personality & 0.634 & \\
& 2.4 Performance & 0.694 & \\
Motivation & 3.1 Intrinsic & 0.515 & \multirow{2}{*}{0.672} \\
(Y1) & 3.2 Extrinsic & 0.925 & \\
& 4.1 Eco-Initiative & 0.783 & \\
OCBE (Y2) & 4.2 Eco-Civic Engagement & 0.687 & 0.534 \\
& 4.3 Eco-Helping & 0.656 & \\
\hline
\end{tabular}

Table 2. Composite Reliability Value from Research Model

\begin{tabular}{cccccc}
\hline Variable & \multicolumn{2}{c}{$\begin{array}{l}\text { Composite } \\
\text { Reliability }\end{array}$} & \multicolumn{3}{c}{$\begin{array}{c}\text { Requirement } \\
\text { Alpha }\end{array}$} \\
\hline $\begin{array}{c}\text { Leadership } \\
\text { (X1) }\end{array}$ & 0.802 & $>0.7$ & 0.778 & $>0.6$ & Reliable \\
Organizational & & & & & \\
Culture (X2) & 0.896 & $>0.7$ & 0.869 & $>0.6$ & Reliable \\
Motivation(Y1) & 0.881 & $>0.7$ & 0.803 & $>0.6$ & Reliable \\
OCBE (Y2) & 0.871 & $>0.7$ & 0.824 & $>0.6$ & Reliable \\
\hline
\end{tabular}

\subsection{Examination of Inner Model Testing}

Before testing the hypothesis, the first step is evaluating the inner model. The Inner Model is analyzed by looking at the significance of the relationship between constructs shown by the coefficient of determination $\left(\mathrm{R}^{2}\right)$, Goodness of Fit Index (GoF), Predictive Relevance $\left(\mathrm{Q}^{2}\right)$, path coefficient and Effect Size $\left(\mathrm{f}^{2}\right)$.

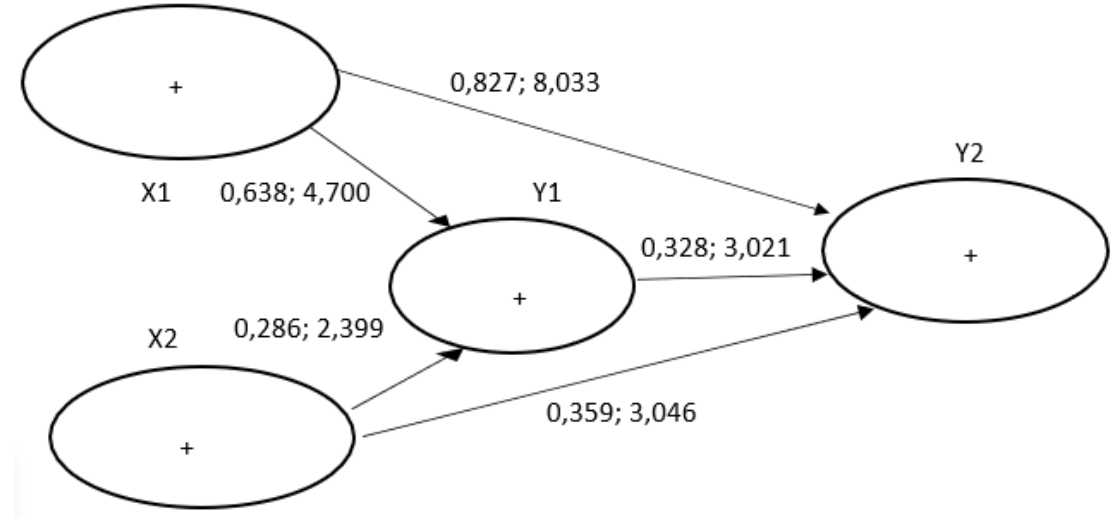

Table 3. R Square Value $\left(\mathrm{R}^{2}\right)$ of the Research Model

\begin{tabular}{cc}
\hline Construct & R Square \\
\hline Motivation & 0.602 \\
OCBE & 0.762 \\
\hline
\end{tabular}

Result of The Smart PLS output concluded that the determination coefficient of this research model can be said to be sufficient on the Motivation variable with an R2 value of 0.602 and on the OCBE variable it can be proper with an R2 value of 0.762 . 
Table 4. Path Coefficient, t-Statistics, and P-Values values

\begin{tabular}{|c|c|c|c|c|}
\hline Hypothesis & $\begin{array}{c}\text { Original } \\
\text { Sample (O) }\end{array}$ & $\begin{array}{c}\text { T Statistics } \\
\text { (IO/STDEV) }\end{array}$ & P Values & Information \\
\hline Direct Impact & & & & \multirow{6}{*}{$\begin{array}{l}\text { Significant } \\
\text { positive effect } \\
\text { Significant } \\
\text { positive effect } \\
\text { Significant } \\
\text { positive effect } \\
\text { Significant } \\
\text { positive effect } \\
\text { Significant } \\
\text { positive effect }\end{array}$} \\
\hline $\begin{array}{c}\text { Organizational Culture - } \\
>\text { Motivation }\end{array}$ & 0.286 & 2,399 & 0.004 & \\
\hline $\begin{array}{c}\text { Organizational Culture - } \\
>\text { OCBE }\end{array}$ & 0.359 & 3,046 & 0.002 & \\
\hline $\begin{array}{l}\text { Leadership -> } \\
\text { Motivation }\end{array}$ & 0.638 & 4,700 & 0.000 & \\
\hline Leadership -> OCBE & 0.827 & 8,033 & 0.000 & \\
\hline Motivation -> OCBE & 0.328 & 3,021 & 0.003 & \\
\hline \multicolumn{5}{|l|}{ Non-Direct Impact } \\
\hline $\begin{array}{c}\text { Organizational Culture - } \\
>\text { OCBE }\end{array}$ & 0.224 & 2,133 & 0.010 & \multirow{2}{*}{$\begin{array}{c}\text { Significant } \\
\text { positive effect } \\
\text { Significant } \\
\text { positive effect }\end{array}$} \\
\hline Leadership -> OCBE & 0.209 & 2,374 & 0.018 & \\
\hline
\end{tabular}

The results of the study stated that leadership has a positive and significant effect on Motivation, Organizational Culture has a positive and significant effect on Motivation, Leadership Positive and significant effect on OCBE, Organizational Culture has a positive and significant effect on OCBE, Motivation has a positive and significant effect on OCBE, Leadership has a positive and significant effect on OCBE through Motivation, Organizational Culture has a positive and significant effect on OCBE through Motivation.

\subsection{Analysis the Influence of Leadership to Motivation}

Leadership influences motivation, It proves that the role of leaders in providing motivation and firmness to employees is very important and needs to be improved continuously and evaluated, AJB Bumiputera 1912 realizes the importance of leaders who provide motivation and work plans that will have a good impact on employee performance at the office especially motivated employees can implement OCBE behavior in the organizational environment by helping team work with one another, creating a good sense of cooperation, and also caring about the condition of the office or organizational environment where they work with the company's goals and objectives in order to be achieved to the maximum. Based on this empirical fact is also supported by Maxwell's theory [5] and supported by the results of previous research, it can be concluded that $\mathrm{H} 1$ can be accepted that leadership influences motivation [8].

\subsection{Analysis of the Influence of Organizational Culture on Motivation}

Organizational culture has an effect on motivation, It proves that the organizational culture of all employees and the top level in the company plays a very important role in motivating employees to play a role in the company where they work, either in terms of performance or in this study we discuss employee voluntary behavior towards the organizational environment (OCBE), where OCBE behavior can be done if the employee 
gets job satisfaction, therefore it is necessary to increase employee job satisfaction so that OCBE behavior is implemented in the organizational environment by all employees, the applied organizational culture can motivate employees to conduct behavioral behavior according to their needs and desires. From the company or organization such as increasing the ability which at AJB Bumiputera activities to increase abilities or skills have been routinely implemented such as training classes, this is good for company performance in a broad scope. Based on these empirical facts [9] and also the results of previous research [10] it can be concluded that $\mathrm{H} 2$ can be accepted that Organizational Culture influences motivation.

\subsection{Analysis of the Influence of Leadership on OCBE}

Leadership influences OCBE, it proves that the behavior of leaders in the company can shape employees to implement OCBE behavior, which helps employees who have difficulty working, conserves water, electricity and uses office equipment according to office needs. Based on these empirical facts supported by Maxwell 2018 theory [5] and the results of previous research, it can be concluded that $\mathrm{H} 3$ can be accepted that leadership affects OCBE [11], [12].

\subsection{Analysis of the Influence of Organizational Culture on OCBE}

Organizational culture affects OCBE, it proves that if organizational culture is disciplined and applied in conserving water, electricity and using office equipment according to office needs, not personal needs, the old OCBE behavior will be formed and permanently carried out by all members of AJB Bumiputera 1912. Based on These empirical facts are supported by the 2018 Robbins theory [5] and the results of previous research, it can be concluded that H4 can be accepted that Organizational Culture affects OCBE [13], [14].

\subsection{Analysis of the Influence of Motivation on OCBE}

Motivation has an effect on OCBE, It proves that there must be a role of motivation among employees, superiors to subordinates, subordinates to superiors in helping to implement OCBE behavior in AJB Bumiputera, slowly the role of motivation is carried out by organizations to be able to implement OCBE behavior in AJB Bumiputera 1912. This empirical theory is supported by the theory of Hasibuan [15] and the results of this previous study, it can be concluded that $\mathrm{H} 5$ can be accepted that motivation influences OCBE [16], [17].

\subsection{Analysis of the Influence of Leadership on OCBE through Motivation}

Leadership has an effect on OCBE through motivation, this proves the role of the leader through motivation to employees in implementing employee OCBE behavior in AJB Bumiputera 1912 environment is very important, especially leaders apply directly and are seen by employees, that the importance of behavior OCBE is applied to minimize office costs incurred for needs that can be saved, employees will more quickly adapt to be able to cause OCBE behavior that is applied in the AJB Bumiputera 1912 environment. Based on these empirical facts and supported by Rivai Mulyadi [7]and the results of previous, it can be concluded that $\mathrm{H} 6$ can be accepted that leadership affects OCBE through motivation [11], [18]. 


\subsection{Analysis of the Influence of Organizational Culture on OCBE through Motivation}

Organizational culture influences OCBE through motivation, this proves the role of organizational culture or habits that must be applied in terms of OCBE behavior, motivation among employees, motivation of superiors to subordinates and motivation of subordinates to superiors, in this case it is very important through culture or habits and motivation to implement OCBE in AJB Bumiputera is very important. Based on these empirical facts and supported by the 2018 Robbins theory [9] and the results of previous research, it can be concluded that $\mathrm{H} 7$ can be accepted that Organizational Culture influences OCBE through motivation [19].

\section{Conclusions}

The study conclusion is the variables Leadership and Organizational Culture affect positively and significantly on Motivation and OCBE (Organizational Citizenship Behavior Environment) in AJB Bumiputera 1912. It suggests that organizations should focus on improving Motivation of employee through leadership and Organizational Culture in order to increase Organizational Citizenship Behavior Environment.

\section{References}

[1] N. Daily, B. F., Bishop, J. W., \& Govindarajulu, "A conceptual model for organizational citizenship behavior directed toward the environment.," Bus. Soc., vol. 48(2), p. ,243-256, 2014.

[2] Hewawasam Puwakpitiyage Rasika Priyankara., "How Does Leader's Support for Environment Promote Organizational Citizenship Behaviour for Environment A Multi-Theory Perspective, Fan Luo 1Amer Saeed.," J. MDI Int., 2018.

[3] R. Ju, S. Y., Azlinna, A., \& Thurasamy, "Environmental leadership and employees' organizational citizenship behavior towards the environment (OCBE): Psychological distance as a moderating variable.," Glob. Bus. Adv., pp. 16-19, 2015.

[4] I. Ghozali, Struktural Equation Modeling Metode Alternatif dengan Partial Least Squares (PLS) dilengkapi Software Smartpls 3.0. Xlstat 2014 Dan Warpls, 4. 2014.

[5] J. C. Maxwell, Developing the leader within you 2.0. HarperCollins Leadership. 2018.

[6] S. M. Obeidat, A. A. Al Bakri, and S. Elbanna, "Leveraging 'Green' Human Resource Practices to Enable Environmental and Organizational Performance: Evidence from the Qatari Oil and Gas Industry," J. Bus. Ethics, vol. 0, no. 0, p. 0, 2018.

[7] M. D. Rivai V, "Leadership and Organization Behaviour.," Rajawali pers;, Prenada Media, 2011.

[8] A. R. Ningsih, "Pengaruh Kepemimpinan Terhadap Motivasi Kerja Karyawan pada PDAM Kota Madiun. EQUILIBRIUM: Jurnal Ilmiah Ekonomi dan Pembelajarannya, 4(2), 192-200.," Equilib. J. Ilm. Ekon. dan Pembelajarannya, vol. 4(2), pp. 192-200, 2016.

[9] P. S. Robbin, "Organizational Behaviour. 9 Edition. New Jersey: Precentice Hall International Inc,” Int. J. Organ. Anal., 2018.

[10] M. D. (2018). Amalia, "Pengaruh Kepuasan Kerja dan Lingkungan Kerja terhadap Turnover Intention Karyawan di PT Mirota Kampus Yogyakarta.," J. Manaj. Bisnis Indones., vol. 7(1), pp. 107-117, 2018.

[11] L. Maduningtiyas, "The influence Leadership and Motivation to OCB in PT GMF Aeroasia.," J. google Sch., 2017.

[12] Q. W. and X. Y. Zhiyong Han, "How Responsible Leadership Motivates Employees to Engage in Organizational Citizenship Behavior for the Environment: A Double- Mediation Model.," J. Res. Gate, vol. 11(3), p. 605, 2019.

[13] B Warsito, "Pengaruh budaya organisasi terhadap OCB dan motivasi pada Cooper, D.R. dan 
Schindler, P.S.,” Bus. Res. Methods. New York McGraw- Hill.

[14] P. Paillé., "Linking perceived corporate environmental policies and employees eco initiatives: The influence of perceived organizational support and psychological contract breach.," J. Bus. Res. 68(11)2404-2411, vol. 68(11), pp. 2404-2411, 2015.

[15] Hasibuan, HR Management. 2014.

[16] S. (2016). Arief, "EFFECT OF ORGANIZATIONAL CULTURE, MOTIVATION AND SATISFACTION THROUGH COMMITMENT TO THE PERFORMANCE OF EMPLOYEES IN THE DEPARTMENT OF LIVESTOCK AND ANIMAL HEALTH SOUTH SULAWESI.,” EPH-International J. Humanit. Soc. Sci. (ISSN 2208-2174), 1(5), 28 54., vol. ISSN: 2208, no. 1(5), pp. 28-54, 2016.

[17] S. N. G. Angelia Simon., "Effect of Work Motivation on OCB through Job Satisfaction.," HUMANIORA, pp. 62-70, 2018.

[18] Hongdan Zhao, "Exploring the Impact of Responsible Leadership on OrganizationalCitizenshi Behavior for the Environment," A Leadersh. Identity Perspect. J. MDPI, vol. 11(4), pp. 1-15, 2019.

[19] A. Nilawati, F., Umar, N., Kusdi, R., \& Zainul, "THE INFLUENCE OF WORK LIFE BALANCE AND ORGANIZATIONAL PRIDE ON JOB SATISFACTION AND ITS IMPACT ON ORGANIZATIONAL CITIZENSHIP BEHAVIOR IN FIVE AND FOUR STAR HOTELS EMPLOYEE.,” Russ. J. Agric. Socio-Economic Sci., vol. 91(7), 2019. 